\title{
The spatial encounter between neoliberalism and populism in Taiwan: Regional restructuring under the DPP regime in the new millennium
}

\author{
Jinn-yuh Hsu* \\ Department of Geography, National Taiwan University, 1, Roosevelt Road, Section 4, Taipei 106, Taiwan
}

Keywords:

Neoliberalization

Populism

State transformation

Taiwan

\begin{abstract}
A B S T R A C T
This paper aims to explore the unevenness of spatial development under the rule of the Democratic Progressive Party (DPP) of Taiwan, after the collapse of the one-party dominance of the Kuomintang (KMT) in the 2000 presidential election. In the late 1980s the KMT engineered the rise of big business groups and consortia with the introduction of its neoliberalization project. To remain in power, the DPP regime continued to implement this neoliberalization project to win the political loyalties and donations from emerging business groups and show a dedication to economic development, while resorting to the populist practice of transferring resources to the local society, particularly winning precincts, to consolidate its advantage and further crumble the KMT bastions. Consequently, Taiwan was a "vacillated state", pulled and dragged between the pro-growth neoliberalization project and calls for a populist redistribution of resources. This resulted in a new political dynamic in which the urban regions were tied closely with the global economic growth while the rural regions were closely tied to domestic resource allocation. As the developmental model of state would predict, this contradictory co-existence of neoliberalism and populism led to a decline in state policy effectiveness.
\end{abstract}

(c) 2009 Elsevier Ltd. All rights reserved.

\section{Introduction: the unexpected rise of the neoliberal populist regime after 2000}

When Taiwan held its first full democratic elections in the early 1990s, the prospects for its democratic consolidation were still uncertain. Taiwan seemed destined to have a one-party-dominant system under the Kuomintang (KMT) party. However, Taiwan's political climate changed radically over the ensuing decade. Taking advantage of a cleavage among between KMT leaders, the Democratic Progressive Party (DPP) won the 2000 election with a fragile majority, mainly due to the support of Taiwan Independency fundamentalists, weak groups whose interest were damaged and more critically - middle class voters who were fed up with the corruption of the KMT state in the development process.

However, the new ruling party inherited a state machinery that was paradoxically leaning towards political favoritism, economic neoliberalism and ideological localism during the later stages of the KMT administration (Hsu, 2006; Zhang, 2005). On one hand, the DPP won support from the ethnic Hoklo communities which occupies over $70 \%$ of population and identified themselves as native Taiwanese. The KMT was accused of being an external colonizing group

\footnotetext{
* Tel.: +886 233665836.

E-mail address: jinnyuh@ntu.edu.tw
}

which slaughtered more than ten thousand Taiwanese people in the notorious "228 event," a massacre that took place on February 28, 1947 when the KMT took over Taiwan from Japanese colonization. In addition, the KMT, mainly controlled by mainlanders who migrated to Taiwan with the KMT party in 1949, insulated key political positions from ethnic Hoklo elites until late 1970s. It led to the undercurrent of searching self-determination in the ethnic Hoklo society. In order to repay supporters for their votes, the new regime offered varieties of subsidies to the Holko communities, mostly concentrated in the South, to reinforce its political stronghold. Most of the allocation of subsidies was made on a personalized basis. Such populist characteristics arose because the new DPP politicians did not trust the old KMT civil officials who had run the government machinery for more than 50 years. The DPP intentionally dodged institutional rules to enforce policies and resorted to personal favors to allocate resources.

At the same time, the DPP regime continued the implementation of neoliberal policies left over by the old KMT administration in order to garner political support and campaign donations. Under these neoliberal policies, a business-friendly relationship became a key tool for the new political leaders who were unfamiliar with the business circle, the turf of the KMT in the past stage. This new policy led to the rise of big business groups and consortia, which were controlled by the old KMT state. Large amounts of capital had been invested in supporting political preferences and exemptions 
under the new DPP regime. A series of neoliberalization policies, including privatization, liberalization, and public-private partnership were raised in the policy package "Challenge 2008" to enhance the national competitiveness (Executive Yuan, 2003).

This paper will address the seemingly paradoxical development of the populist DPP regime engaging in the neoliberalization project. In the following section, a theoretical context will be offered on neoliberalization, populism and scale politics to handle the issue of state transformation and regional development. This will be followed by a detailed discussion of the political transformation and economic restructuring in the DPP regime. In this discussion, the regional impacts of neoliberalization and populism will be identified empirically and explored theoretically. Divergent changes in regional and community scales emerge in the process of state transformation. Finally, the concluding remarks will focus on neoliberalization and the developmental state.

\section{Theoretical contexts: neoliberalization, populism and scale politics}

\section{The political project of neoliberalism-cum-populism}

Scholars did not expect populism and neoliberalism to coexist. Populism was conceived to allow leaders to attract a large following by enacting mass-incorporating, moderately redistributive policies (Roberts, 1995). In contrast, neoliberalism would include tough austerity measures and limited distribution of benefits and was therefore expected to antagonize the masses of the poor (Sachs, 1989). Scholars concluded that politically-driven clientelism could not survive peacefully with economically-calculated rationality. The consideration of the former often led to the failure of the latter. In other words, political populism would impede the development of economic liberalism.

Nevertheless, the surprising convergence of these two seemingly contradictory practices emerged in a number of developing nations, particularly some Latin American countries such as Argentina, Brazil and Peru in the late 1980s. If neoliberalism means "accumulation by dispossession", as Harvey (2005) illustrates, then how it tolerates "irresponsible" spending on the part of charismatic politicians is puzzling. Different strategies have been adopted by scholars to attack this conflicting issue from varieties of perspectives.

First, a group of scholars claimed those political leaders who adopted "unpopular" economic policies would no longer be populists. For example, Palermo (1998) refuted the notion that Argentina's Menem was still a populist when he enacted market reform. Nevertheless, such disavowing arguments did not explain why populism became unpopular at sites of neoliberal transformation.

Second, some scholars saw populism as a short-term response to electoral pressure employed to cover up the long-term neoliberal projects. Johnston and Glasmeier (2007) asserted that the missing issue in the neoliberalization process was the consideration of party politics. In domestic politics, neoliberal goals may be subordinated to others, such as populist policies, which were, in effect, more selfserving for the government concerned. In such circumstances, neoliberal policies were usually delayed and short-term and more spatially selective policies prevailed. Moreover, the rationale for this short-termism was often based on electoral politics. As winning (re)election is a primary goal of any democratic government, it would introduce significant temporal and spatial constraints to political actions which might have deleterious effects on the wellbeing of their supporters. In other words, the long-term neoliberal plan could remain intact, ironically, under the shield of populist policies.

Third, scholars such as Roberts (1995) and Weyland (2003) not only took the marriage of populism and neoliberalism seriously, but advanced the arguments that these two ideologies were compatible and even had some unexpected affinities. They argued that populism in general was a political strategy with a low level of institutionalization, and this anti-organizational bent of populism was shared by neoliberalism which sought to protect the market from interference by special interests and rent-seeking groups. The undifferentiated mass of "the people" following the leader was akin to the unstructured market. Such viewpoints took a political definition of populism as a specific way of competing for and exercising political power. As asserted by Weyland (2003), the political definition captured the goal of populist leaders who aimed to win and exercise power by using economic and social policies as an instrument for this purpose. It was most attuned to the opportunism of populist leaders and their weak commitment to substantive policies, ideas, and ideologies. In other words, neoliberalism and populism could be convenient bedfellows in that both espoused anti-elite/bureaucrat rhetoric and challenged the status quo and enhanced the political power and economic gain of the leaders. No wonder many populist regimes become beset by instability and corruption, though the stated goal is to promote justice and equitable growth.

As is the case with the political definition of populism, this paper conceives neoliberalism as a political project which was best characterized not as a coherent end product, but rather as a complex and contested set of processes comprised of diverse policies, practices, and discourses (Larner, 2003). Accordingly, the key issues were not to identify what constituted the tenets of neoliberalism, but to address the diversity of political contexts and the range of effects generated in the neoliberalization process. With such understandings, it was clear that institutions were not so much neutral coordinating mechanisms as they were structures that were biased towards particular patterns of power distribution in society. Particularly, the state, among other institutions, was the incarnation of the political struggle of confronting power blocs, and would affect the result of new rounds of power struggle. In comparison with the previous two perspectives, this extended political definition of populism and neoliberalism would recognize that the enactment of neoliberal agendas did not entail the seamless imposition of a uniform, hegemonic template, but dynamic and contingent processes that occur in uneven and contested ways in highly varied contexts (Larner, 2003).

This populism-cum-neoliberalism perspective was of special interest in the case of developing states in East Asia, such as Korea and Taiwan, which, rather than conforming to the neoliberal model of market priority, played a leading role in post-war economic development (Brohman, 1996). In contrast to the welfare model of market economies which offsets the poverty of the 'losers' with the wealth accumulated by the 'winners' through social security transfers, the 'developmental market economy' embedded this redistribution of resources in its own fundamental institutions (Tsai, 2001). To some extent, the priority of economic development sacrificed the level of social demand, such as the lack of social infrastructure and unemployment issuance in the East Asian developmental state.

However, in the mid-1980s, the state began to implement a package of liberalization policies and retreated from various productive activities. At this point the state could have become dismantled by neoliberalism or a specific type of hybrid governance model might have emerged. By taking neoliberalization as a political project, this perspective could shed light in decoding a key myth in the transformation of the East Asian developmental state: the symbiotic emergence of the roll-back of state intervention in economic development and the roll-out of state subsidization in social spending. Such a symbiosis has a geographical dimension. 
Regional restructuring and scale politics

Recent theoretical work in neoliberalization research has generated a number of important insights that could have significant implications for empirical research on political-economic restructuring at all spatial scales (Brenner \& Theodore, 2002; Gough, 2002; Peck \& Tickell, 2002). The process of remaking space in the neoliberal image is, however, a contradictory one. As a matter of fact, neoliberalization generates path-dependent, rather than convergent, outcomes as it does not engender identical (economic, political or spatial) outcomes in each context in which it is imposed. Rather, as place-, territory- and scale-specific neoliberal projects collide with inherited regulatory landscapes, contextually specific pathways of institutional reorganization reflect the legacies of earlier modes of regulation and forms of contestation (Brenner \& Theodore, 2002; Peck, 2004). In most cases, neoliberal spaces cannot be filled with truly neoliberal rules or institutions, but must be constructed as hybrid spaces composed of neoliberalization and established regulatory strategies (Park, 2005). It is the hybridization of spatiality that characterizes the divergent configurations of the neoliberalization which in turn shapes the different trajectories of local and regional development.

In this sense, instead of eroding the production of the national as a relevant scale, the politics of neoliberalization has refashioned state structures through the upwards and downwards rescaling of powers to international, regional, local and communal entities (Jessop, 2002). In this rescaling process, an urban-regional renaissance is warmly embraced and the rise of new regionalism represents an explicit attempt to engage with the changing geographical contours and forms of the economy in what increasingly appears to amount to a 'postnational capitalist world order' (Scott \& Storper, 2003). It is usually argued that localities, regions, and nations are all under the shade of global competition, no matter that they are participating actively, even if by force, to become incorporated in the systematic integration. Without becoming a regional node in the global network, these places would no longer prosper and survive in this ruthless global competition. In place of the hollowing-out nation state, these regions become the locus of competitiveness in the friction-free neoliberal economy (Jessop, 2001; MacLeod, 2001). As a result, a global tendency towards devolution of authority and resources from nation-states to regions and localities occurs and city-regions become sites of exchange, innovation, development and competition (Rodríguez-Pose \& Gill, 2003; Ward \& Jonas, 2004).

But, as warned by Gough (2002), given the emphasis on exchange relations and strategic competition, corresponding attention to the social relations of production, consumption, and redistribution and their underlying geographies of conflict are, at best, limited. While not denying the importance of the role of certain city-regions in the shaping of geographies of competition, innovation, and economic development, Ward and Jonas (2004) argue that it is neither historically necessary nor spatially inevitable, but is the contingently structured medium and outcome of struggle and strategies of divergent scales of territorial management (also see Rossi, 2004). In particular, community-based programs are often deployed to alleviate the social exclusion created by the neoliberalization process. It aspires to address community development through 'bottom-up' empowerment rather than more traditional 'top-down' allocation approaches, and is based on the idea that communities themselves have the best knowledge of their social service needs, or that they could readily determine these if they had the resources to do so (Larner, 2005).

The community movement is often taken as a form of partnership between the government and voluntary organizations. In other words, the community scale becomes a part of the neoliberal governance mechanism, which is a broader configuration of state and key elements in civil society. Jessop (2002) sees the rise of partnership, which consists of community empowerment, as an example of a flanking compensatory mechanism for the inadequacies of market mechanism, rather than representing a new form of social governance based on trust and collaboration. Accordingly, in the recalling process, the community becomes the pivotal site of governmental technique for the political project of neoliberalization (Larner, 2005). In fact, community movement, in some sense, echoes the appeal of populism which formally adopts the bottom-up approach to resource distribution while following the top-down mobilization of political leaders in reality. In brief, community space embodies the governmentality of the political project of neoliberalism-cum-populism.

\section{Political crisis and economic restructuring after the 1990s}

Neoliberalization measures, such as privatization, financial liberalization and public-private partnership, took place in Taiwan in the late 1980s (Hsu, 2006). The key dynamics behind these policy changes came from domestic political struggle and global economic competition. Politically, an omen of the end of strongman politics emerged and aroused power struggle among different factions within the ruling body in the early 1980s. A series of protests were organized by the oppositional groups to attack the one-party ruling system and demand democratization. These groups were composed mainly of the urban bourgeoisie who ironically benefited from the state-led economic development and the ethnic native Taiwanese elites who sought to be independent from Mainland China. The oppositional party, the Democratic Progress Party (DPP), was allowed to form in 1987 after numeral fights for democratization. To meet the external challenge from the DPP and the power struggle with mainlanders within the KMT party, President Lee Deng-hui launched an "indigenization" strategy, which aimed to join forces with the politicians of local factions to form a political majority. The authoritarian developmental regime gradually lost its arbitrary power and had to win support from local factions and business groups which emerged in the liberalization process (see Table 1 ). As a result, the business groups played an increasingly critical role in industrial policy making.

This was a brand new phenomenon in the post-war industrial development in Taiwan, which was noted by its SME model, as shown above. According to Amsden and Chu (2003), the core business of the top 100 groups was initially in manufacturing, which accounted for $85 \%$ of production value through the early 1980s. Nevertheless, over time an increasing number of groups focused their core activities in the service sector; as many as 23 groups out of 104 in 1996, besides a few electronics firms, based their success in high-technology development, joining the list of the top 100 businesses in early 1990s. The liberalization policy rapidly consolidated the growth of business groups, as newly opened industries such as telecommunications, cable TV, and power plants were embraced by these groups. The ratio of the total revenue of the top 50 business groups to the GDP (Gross Domestic Product) increased from 35\% to 52\% from 1993 to 1999, and the ratio for the top ten groups increased from $18 \%$ to $25 \%$ during this period. In most cases, new commercial banks became the core actor by financing their subsidiaries to invest in these new industries.

In addition to the political transition, the issue of economic restructuring brought forth challenges to Taiwan in the 1980s. In the beginning, an acute shortage of cheap labor and land arose. In the meantime, the rise of the late-latecomers such as the Southeast Asian industrializing countries and mainland China created a rivalry in the international markets and attracted capital (Chung, 1997). An investment strike occurred after 1980, and the domestic 
Table 1

Top 100 business groups' sales and employment as a percentage of GNP, 1973-1998.

\begin{tabular}{|c|c|c|c|c|c|c|c|c|c|c|c|c|c|}
\hline \multicolumn{14}{|c|}{ Unit: US\$ billion, thousand people, \% } \\
\hline & 1973 & 1975 & 1977 & 1979 & 1981 & 1983 & 1986 & 1988 & 1990 & 1992 & 1994 & 1996 & 1998 \\
\hline Top 100 sales $(\mathrm{A})$ & 3.5 & 4.3 & 6.2 & 10.6 & 13.4 & 15.8 & 23.7 & 43.4 & 62.3 & 73.4 & 101.5 & 121.3 & $\overline{150.6}$ \\
\hline Growth rate, \% & - & -4 & 14 & 19 & 1 & 9 & 9 & 21 & 15 & 2 & 18 & 9 & 20 \\
\hline GNP (B) & 11 & 15 & 22 & 33 & 47 & 52 & 83 & 128 & 163 & 215 & 250 & 297 & 328 \\
\hline Percentage (A/B) & 32.3 & 28.0 & 28.7 & 31.9 & 28.8 & 30.1 & 28.7 & 33.8 & 38.3 & 34.2 & 40.6 & 42.9 & 54.0 \\
\hline Top 100 employment (C) & 277 & 283 & 300 & 313 & 308 & 330 & 335 & 375 & 397 & 436 & 489 & 577 & 770 \\
\hline Growth rate, \% & - & 1 & 3 & 2 & -1 & 4 & 1 & 6 & 3 & 5 & 6 & 9 & 17 \\
\hline Total employment (D) & 5125 & 5521 & 5980 & 6426 & 6672 & 7070 & 7733 & 8108 & 8283 & 8632 & 8939 & 9608 & 9289 \\
\hline Percentage (C/D) & 5.4 & 5.1 & 5.0 & 4.9 & 4.6 & 4.7 & 4.3 & 4.6 & 4.8 & 5.0 & 5.4 & 6.3 & 8.3 \\
\hline Group number & 100 & 100 & 100 & 100 & 100 & 96 & 97 & 100 & 100 & 100 & 100 & 100 & 100 \\
\hline Collected CCIS & 111 & 106 & 100 & 100 & 100 & 96 & 97 & 100 & 101 & 101 & 115 & 113 & 179 \\
\hline
\end{tabular}

Source: adopted from Amsden and Chu (2003) Table 4.1 (p. 121).

investment rate declined from $32 \%$ in 1981 to $16.3 \%$ in 1986 . The savings rate rose gradually during the same period (Liu, 1992). This indicated that the capital's confidence in the investment climate was shaken. Worst of all, the harsh pressure of opening domestic markets and liberalizing the exchange rate from the US and the intention to join the WTO (World Trade Organization) in early 1990s further deteriorated the established competitiveness of the export-oriented economy.

A systematic reshuffling of the political economy occurred in the mid-1990s. By caressing the demands from the key business groups, the government tried to counter the magnetic power of investing in China, which was taken as an enemy politically. An ambitious project, Asia-Pacific Regional Operation Center (APROC), was rolled out by the government in 1996. The project demonstrated the government's ambivalent attitude towards China. On the one hand, the opening of China represented a huge reservoir of cheap labor and land for those Taiwanese SMEs who could not survive. On the other hand, however, the rise of China represented a fatal attraction for Taiwanese investors, particularly those hightechnology and big business groups, who would relocate to the territory of the political enemy at the expense of Taiwanese interest. The APROC project aimed to act as a hub for regional manufacturing, sea and air transportation, financial, telecommunications and media activities. The project was seen as requiring an open and competitive economy which included privatization of state enterprises, liberalization of the domestic market, and the institutionalization of BOT (Build, Operate and Transfer) or encouraging the participation of private capital in the construction of public infrastructure. As a result, the pattern of regional development no longer was shaped solely by the state, but by an alliance between the government, business groups, and local political factions.

But the APROC project was abruptly abandoned after the surprising victory of the opposition party, the DPP, in the 2000 presidential election; a victory that ended the more than 50 years of single-party-rule by KMT. Thanks to electoral support from the South, the DPP won re-election in 2004 (See Fig. 1).

The DPP regime was worried by its lack of experience in economic affairs, an area in which the KMT developmental state enjoyed a good record. Accordingly, a new policy package, Challenge 2008 (Executive Yuan, 2003), was proposed to signal a distinction from the KMT's APROC project. The essence of the new project aimed to handle two issues. Firstly, the project was meant to support the continued implementation of neoliberalization projects in order to win the political loyalties and donations from the emerging business groups, and to show its dedication to economic development. Secondly, this project resorted to populism to transfer resources, partly through a series of community empowerment movements, to the local society, particularly those winning precincts, to consolidate and amplify its edge while crumbling the KMT bastions. Neoliberalization and populism coexisted in the DPP political space.

\section{The populist centralized regime and scale politics in the new millennium}

\section{Raising the stakes in the neoliberalization project}

The DPP pushed for liberalization much harder than its precursor because it was required to cultivate relationships with business groups which also wanted to caress the new regime. The formation of financial business groups serves as an example. The DPP promoted the establishment of financial holding companies (FHC) by providing huge incentives, such as tax breaks and new business activities in 2001. The new regulation would allow the FHCs to cross-invest in varieties of financial commodities such as insurance, securities and futures, with the intention of making the FHCs big enough to compete internationally. Moreover, due to the abrupt increase of bank number, an issue of "overbanking"1 and idle-loans incurred by some of the new banks, particularly those closely connected with local factions, became imperious for the new DPP government to handle. Consequently, waves of acquiring and merging (A\&M) have been proposed and encouraged by the state (see Table 1 ). ${ }^{2}$ By doing so, the key FHCs, such as Cathay, Fubon, HsinKong, and Chinatrust, increased their assets very rapidly. ${ }^{3}$ Moreover, according to the law, the FHCs were allowed to set up new branches in one area to replace the ones in other areas in their A\&M activities. While the number of branches was strictly controlled by the state to avoid financial disorder, the A\&M measure was the critical option to be utilized by the new FHCs to add new branches to compete in the urban regions (Xia, 2005). For instance, YuShan group merged with Kaohsiung Business Bank and closed 23 branches of the latter and moved them to Taipei. A similar situation occurred when the Sinpac Group merged with Taitung Credit Union to replace branches in Taipei, while Chinatrust group shut down six branches of FengShan Credit Union and relocated them to the North region (see Fig. 2). According to a statistical report by the Financial Supervisory Commission (FSC, 2008), over one third, or 126 out of 319, of townships in Taiwan were surprisingly not home to a single bank branch. Between 2002 and 2007, 109 bank branches were established in Taipei, while 48 branches closed in Pingtung, Kaoshuing, Tainan, Chiayi and Taitong counties, mostly located in the remote districts in the south of the country. All of these cases showed that financial service in the rural areas, particularly in the south, were decreasing (Table 2).

The phenomena of financial exclusion were exacerbated in the wave of consolidation of credit departments of farmers associations in 2002. As most of the associations were manipulated by the local factions that constituted the pillar of control in the clientelism of 


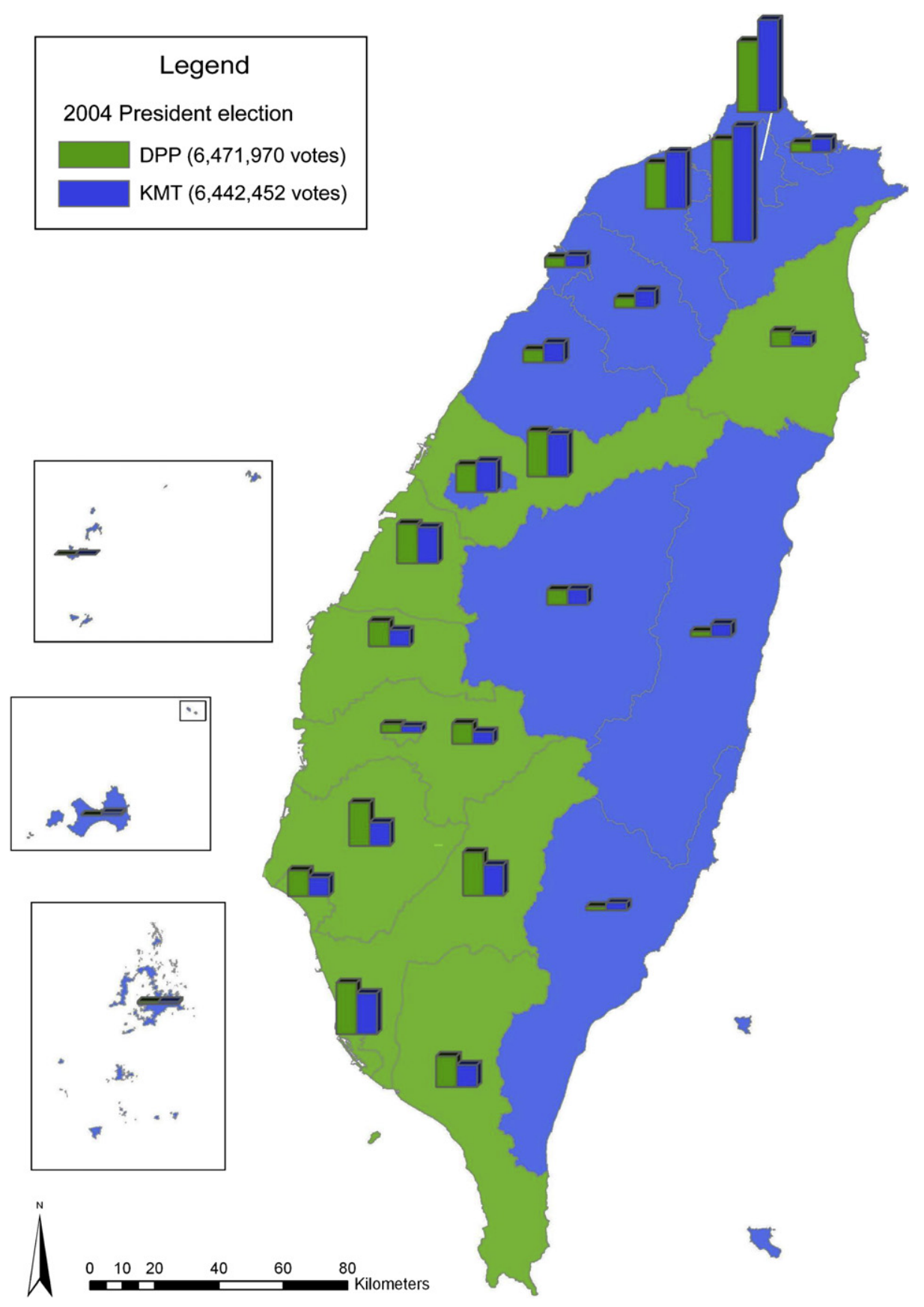

Fig. 1. The winning precincts of 2004 presidential election.

the KMT state, their credit departments usually played the role of local financial centers in the rural areas and were embraced by the local factions which notoriously involved in abuse of the credit departments. Among the 285 farmer associations throughout Taiwan, 100 of them had accumulated up to $25 \%$ of non-performing loans (NPLs), and the average NPL rate amounted to $34.76 \%$ as of 2002 (Liu, 2002). The DPP government estimated that it cost taxpayers nearly NT\$1 million a day to plug the hole. Under such circumstances, the government, for sake of reform, demanded that the banks take over these credit departments from 1997 on, and 27 departments disappeared in the rectification process. With this action, the DPP aimed to cut off the links between the grassroots associations and the KMT. However, it deteriorated financial exclusion in the rural areas, since most of the customers who depended on the lending from the associations would be unbanked or excluded from financial services if those specialized financial services did not exist, as noted by Leyshon and Thrift (1997) and Valverde and Fernandez (2004). This move enraged the farmers and more than 120,000 protested and consequently forced the minister of finance to resign.

The DPP government took over privatization policy since the State-Owned Enterprises (SOEs) were taken as the surviving supports of the KMT party. In addition to the intention to eradicate the activities of the KMT capital in the SOEs, the DPP administration found the SOEs could be used both to reward its followers and to profit the new business groups. ${ }^{4}$ The government sold the stateowned lands, particularly those in the urban areas, to the business groups. According to a report (OURs, 2006), more than 220 billion 


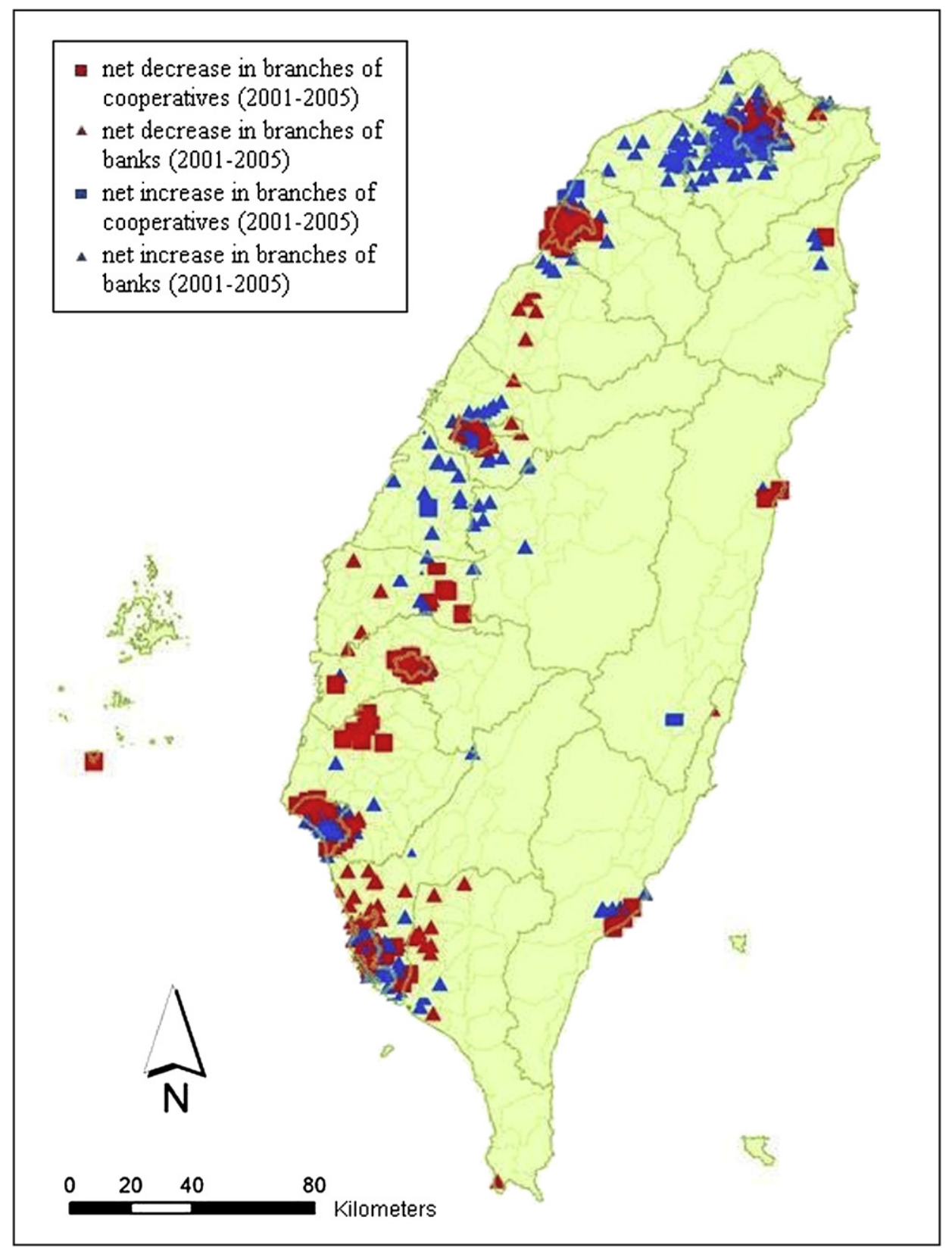

Fig. 2. Bank branch openings and closures accompanying financial Acquisitions and mergers (A;M).

NT dollar valued of lands were privatized from 2001 to 2005. Those business groups who owned and developed these lands would earn extravagant profits from the privatization process. ${ }^{5}$

The DPP government extended the idea of Public-Private Partnership (PPP) to cover new infrastructure construction, such as the Kaohsiung Rapid Transit System (RTS) and Taipei-CKS airport RTS. As the infrastructure construction projects always involved more than hundred million dollars in investments, the idea of PPP came true in the embrace of the business groups and their consortia. Take the example of the project of the High-Speed Rail (HSR) as an example. The HSR was proposed by the KMT state to enhance the competitiveness in the APROC project. Also it was designated as the demonstration of the PPP since the construction cost was too huge, estimated up to 440 billion NT dollars which was the largest BOT deal in the world, to be solely handled by the state. In 1997, the THSR which was led by Continental Engineering Corp and other key business groups won the BOT bid. In the agreement with the government, the THSRC promised to take the financial burden without the government's investment, and would freely transfer the ownership of HSR to the government after 35 years of operation. But, in practice, the High-Speed Rail (HSR) ironically became a liability since the DPP government, through the governmentcontrolled funds, agreed to invest more than $50 \%$ of the construction cost after the THSRC refused to add their capital investment in 2005. Such an act obviously violated the idea of BOT, but was tolerated by the DDP government which built close relations with the members of the THSRC consortia.

Of course, lunch was never free. To compensate for THSRC's construction costs, the government allowed land development around the stations. Five of the ten stations, including the key cities of Taoyuan, Hsinchu, Taichung, Chiayi and Tainan (See Fig. 3), were equipped with the state zone development which covered station 
Table 2

Acquisitions and merging (A;M) of banks during the DPP rule.

\begin{tabular}{|c|c|c|}
\hline Legal merger date & Surviving company & Merged company \\
\hline 2002.02 .18 & Taishin Bank & Daan Bank \\
\hline 2003.10.27 & United Bank (renamed Cathay United Bank) & Cathay Bank \\
\hline 2003.12.01 & Chinatrust Commercial Bank & Wan Tung Bank \\
\hline 2004.09 .04 & E. Sun Bank & Kaohsiung Business Bank \\
\hline 2004.09.30 & Shin Kong FHC (renamed Shin Kong Commercial Bank) & United-Credit Commercial Bank \\
\hline 2005.01 .01 & Taipei Bank (renamed Taipei Fubon Bank) & Fubon Bank \\
\hline 2005.03.19 & Union Bank of Taiwan & Zhong Xing Bank \\
\hline 2005.10 .03 & Taiwan Shin Kong Commercial Bank & Macoto Bank \\
\hline 2005.10.29 & Sunny Bank & Kao Xing Bank \\
\hline 2005.12.31 & Macoto Bank (renamed Taiwan Shin Kong Commercial Bank) & (Shin Kong Commercial Bank) \\
\hline 2006.05.01 & Taiwan Cooperative Bank & Farmers Bank of China \\
\hline 2006.08.21 & International Commercial Bank of China (renamed Mega International Commercial Bank) & Chiao Tung Bank \\
\hline 2006.11.13 & SinoPac FHC & International Commercial Bank of Taipei \\
\hline 2007.06.30 & Standard Chartered Bank & Hsinchu Business Bank \\
\hline 2007.09.08 & Chinatrust Commercial Bank & Hualien Business Bank \\
\hline 2007.09.22 & ABN AMRO Bank & Taitung Business Bank \\
\hline 2007.12.01 & CitiBank & Overseas Chinese Bank \\
\hline 2008.03.29 & HSBC & Chinese Bank \\
\hline
\end{tabular}

Source: FSC, 2008.

land, peripheral passenger transfer facilities, other transportation facilities, and more importantly, "enterprise development lands" used for subsidiary commercial enterprises such as hotels, conference and trade show centers, restaurants, recreation venues, department stores, financial services and office buildings. According to the BOT agreement, THSRC would have the right to use the enterprise lands for 50 years. Land development became the key source of profit for the THSRC business groups (Chu, 2003). The

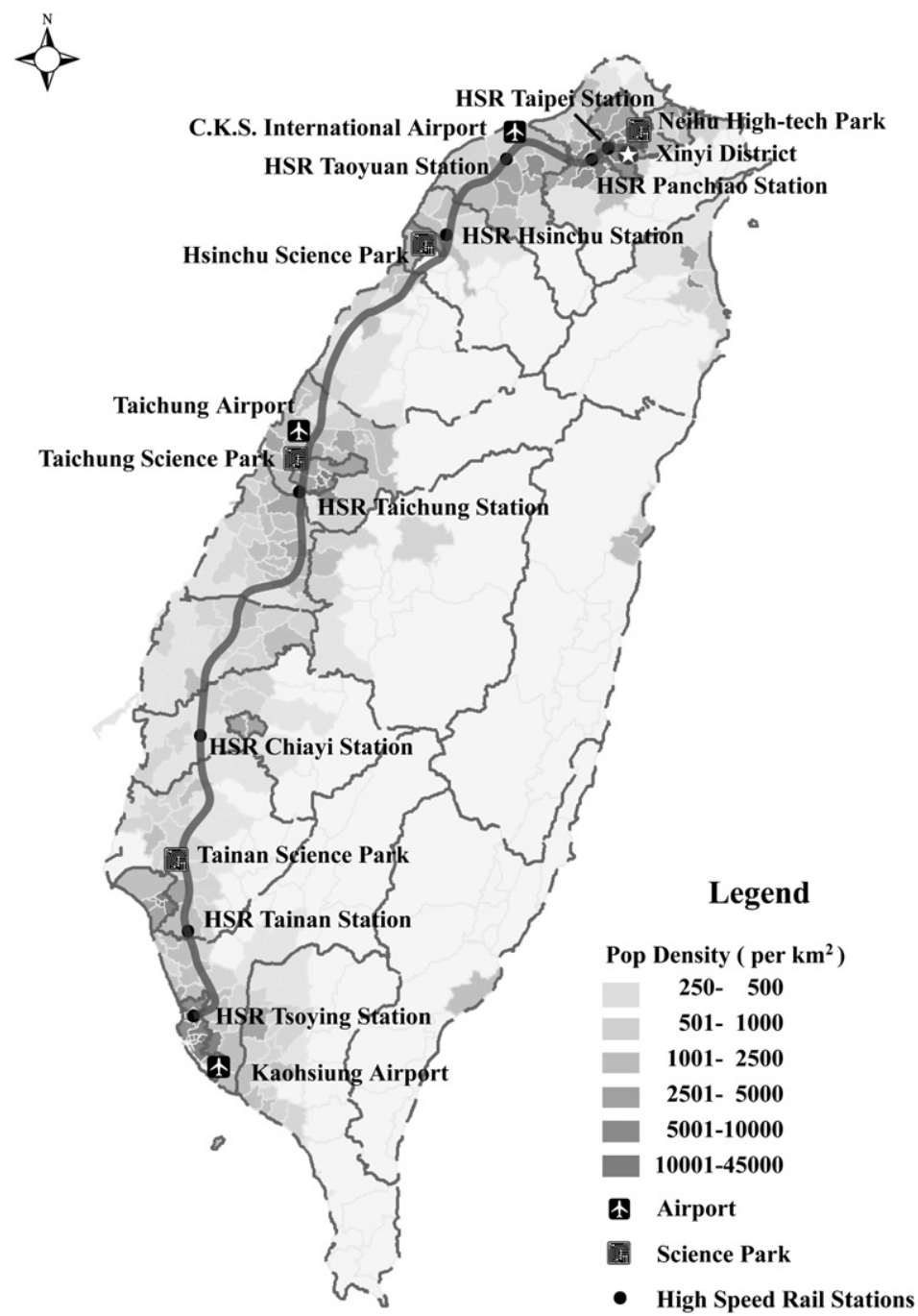

Fig. 3. The locations of key investment projects. 
resultant spatial effect would be that the rural areas, even those small towns, were further ignored in the new transportation landscape. Like magnets, these HSR stations would attract the leading industries to locate around the station's special zones and the neighboring areas. As for the remote districts, their fates were disregarded by the THSRC plan for lack of profit.

\section{Consolidating the supporting turfs by mobilizing populism}

In addition to carrying on KMT's neoliberalization policies, the DPP government had to respond to the demands of its supporters who were mostly based on the Southern region. In fact, as a centralized state, the DPP government could transfer resources to its supportive precincts according to the tax revenue allocation laws. As the government reports (CEPD, 2004) showed, the Southern region, which was mainly the DPP turf, received aid and subsidies from the central government totaling NT\$76,185 million, or $40.8 \%$ of its revenue, in 2003. In contrast, the Northern region, where KMT won the majority vote but lost the largest precinct (Taipei County), received NT $\$ 70,056$ million, or $24.2 \%$ of its revenue. Among the revenue received by the Northern region, Taipei County, ruled by DPP, got NT\$33, 159 million while Taipei City, controlled by a KMT major who was believed to be the most threatening challenger in the next election, received only NT\$4545 million.

Under the populism of the DPP regime, it was difficult for the Northern Region (mainly the corridor extending from Taipei to Hsinchu) which hosted most of Taiwanese high-tech firms to keep its advantageous position as a node connecting Taiwan to the technology hub in Silicon Valley and extending the high-technology investment across the Strait (Hsu, 2005). But, in the eyes of the inward-looking government, the movement of investments to China would endanger economic growth and national security. To retain the investments locally, the state adopted two policies; one the stick, and the other carrot. Those investments that were not reported to the government resulted in fines and some of the investors were even sentenced to prison. This situation forced many Taiwanese investors, particularly those high-technology firms, to choose to register in a third country, such as the Cayman Islands, as foreign companies to engage their Chinese investments rather than report these dealings to the Taiwanese government. Also, the policies did not allow direct linkages (trade, postal and air transportation) between Taiwan and mainland China. Consequently, these "sneaking" investments added cost to the producer service providers and did nothing to enhance the Hsichu-Taipei regional advantage (Ching, 2001).

To compensate for the loss incurred by not investing in the cheap land of China, the government eagerly offered land subsidy and fiscal benefit to keep business rooted in Taiwan. Consequently, a new science and technology park in southern Taiwan, the Tainan Park, was planned and launched in 1995. The Tainan Park was initially designated as an extension of the Hsinchu Park to offer subsidies for the semiconductor firms to expand their mature operation without moving to China. ${ }^{6}$ The construction of the Tainan Park was enthusiastically embraced by the new DPP government as it could serve the DPP's strategies to care for the needs of the South. This magnified the politically-manipulated-infrastructure in the case of the Taichung Park, the third science and technology park proposed by the DPP government. The case of Taichung Park will be discussed in further detail later.

The key space in which populism existed was within the community empowerment movement. It was initiated by the President Lee of the KMT in 1994. The state promoted the movement to build up communities in which the local residents organized to construct their community identity, by acknowledging the history of community development with the financial support from the government to regenerate the moribund localities. Moreover, this identity was mobilized to build up the spirit of "new homeland" which politically symbolized a new Taiwan nationalism that was to be distinguished from mainland China (Huang, 1996). Under such political motives, a number of community empowerment projects, with a budget of NT\$12.6 billion from 1994 to 2000, were carried out across the countryside (The Control Yuan, 2001).

After gaining power, the DPP administration followed the community empowerment policy closely. The community movement summoned by the DPP aimed to involve direct participation of the people as a way of circumventing the institutions and associations of representation which they believed had been contaminated by the KMT longtime ruling. In contrast to the clientelism of KMT regime, the DPP resorted to populism which emphasized the injustice of regional disparity and strengthened the identity of local communities. By doing so, the DPP aimed to break up the dominance of the local KMT factions and replace them with pro-DPP community organizations. This is a clear power struggle resulting from the nature of top-down party politics. Besides, to compensate for economic loss and strengthen political control, the government allocated community development resources to impoverished areas to strengthen support for the DPP. The DPP government extended the community empowerment policy to cover more policy areas, such as the newly established Hakka-people and aboriginal-people affairs, which were believed to be KMT's territories. The government spent more than 410 million NT dollars in the community organizations in the Hakka and aboriginal tribes from 2004 to 2007 (see Fig. 4).

Most of the community projects allocated budgets in the construction of community infrastructure, such as historical museums and community culture centers, the holding of cultural and social festivals and the compiling of local histories. Accordingly, the community projects indeed revitalized some of the declining villages with tourist resources such as the Sun-Moon-Lake area for tourism development. However, the projects also developed community infrastructure on a smaller scale by funding public activity centers, community libraries and senior centers. Most of these projects were not in urgent demand and became pork barrel infrastructure. As reported by the ministry of justice (TMJ, 2005), about 147 such small infrastructure projects had become idle and wasted around NT\$41 billion until the end of October 2005.

\section{Devolution in appearance, centralization remains intact}

The central-local relationship went through three major phases of transformation since the KMT party retreated from mainland in 1949. Clientelism had long been viewed as the key to understanding the KMT's maintenance of long-term, stable, authoritarian rule in Taiwan (Wu, 1987). Through clientelism, the KMT rewarded local factions with political and economic privileges, and in return, local factions helped the KMT rule areas that it found difficult to penetrate and played a preemptive role in eliminating anti-KMT forces in ethnic Hoklo regions. The local factions wholly encroached on the neighborhood construction projects, such as road and bridge buildings, and the local credit unions and the agriculture and fishery associations which played the key financial centers in the rural regions. In most cases, at least two competing factions were fostered by the KMT party which control local factions by the policy of "divide and conquer". At this stage, the central-local relationship was characterized as a form of centralization, and the major mission of local government was to play an administrative unit for local affairs.

Things changed gradually after the founding of the DPP in 1987. The DPP gained political momentum by emphasizing the clearing of "black-gold", which targeted the KMT - who orchestrated for the local factions to deploy vote-buying and even violence to control 


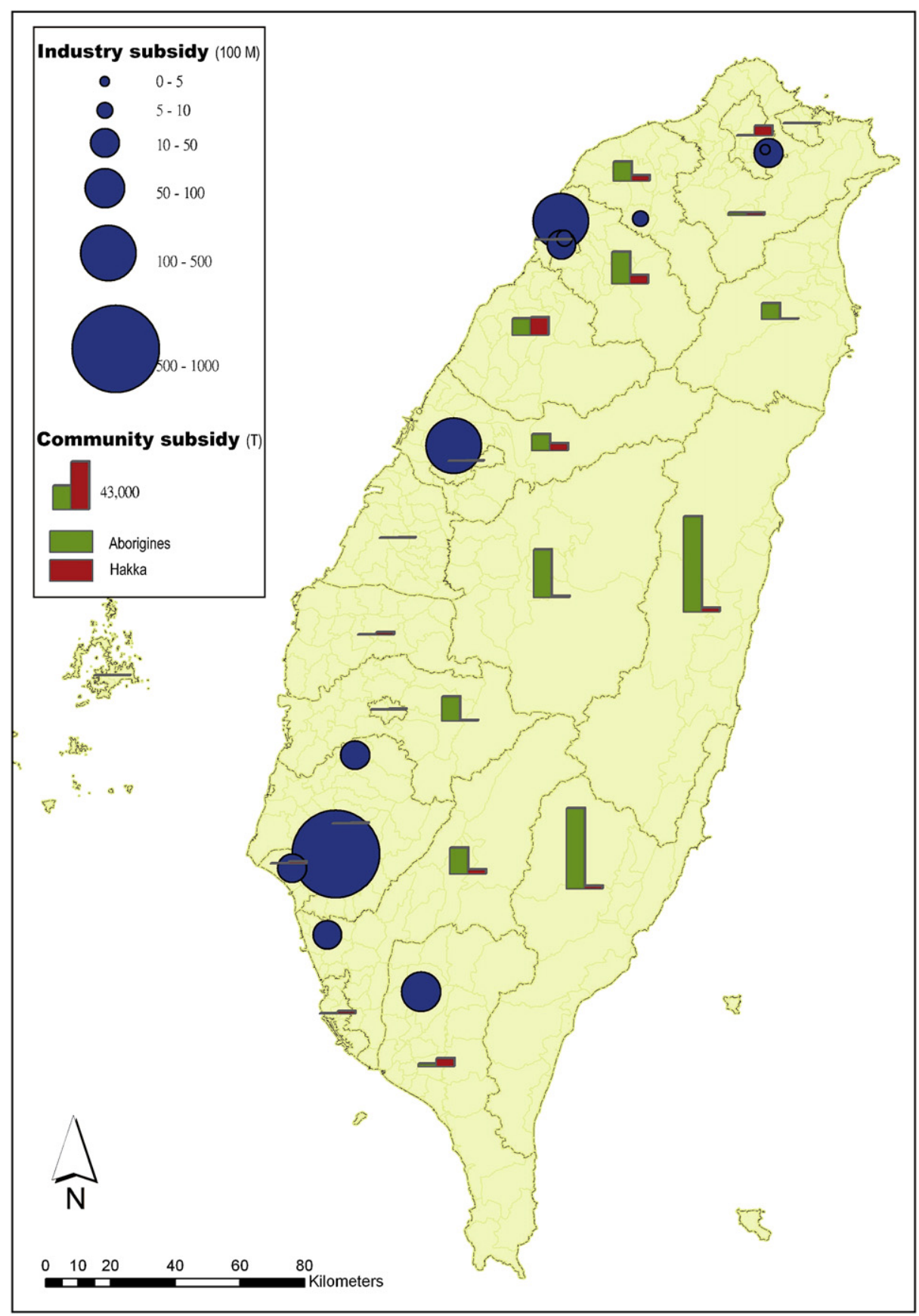

Fig. 4. The distribution of community projects and industry subsidies.

local interests - the brokerage role played by the local factions gradually paralyzed. Wang and Kurzman's (2007) empirical study of a local election in 1993 demonstrated the failure of clientelistic mobilization because of the challenge from the DPP, who took advantage of the contradictions of the competing factions in the interest distribution. "The envelopment of central government by the encroachment of the local" was designed as a key strategy for the DPP to gain power in the political struggle with the KMT (Zhang, 1989). This led to the rapid growth of DPP in a series of election, as evidenced in the 1993 local election where they gained around $42 \%$ of the vote. Controlling local governments was no longer taken for granted by the KMT. In particular, the status of the central government was appreciated after the rule of the presidential election changed from indirect to direct vote in $1996{ }^{7}$
Local politicians became the key agents in brokering voting support from their local bases. The political influence of local government and factions magnified in the process of power restructuring. More money and power were allocated to local level, according to the amendments to the Local Government Law in 1998. However, the final decision-making on fiscal and personnel policies was still conducted by the central government.

The third phase of central-local relation came after the DPP won the presidential election by a slim margin in 2000 . To break the blockade of the local factions by the KMT, the DPP's presidential candidate, Chen Shui-bian, promised to build up new but equal central-local relations in which the local government would be granted more power to participate in the decision-making system. An agile local government would replace the role of a cumbersome 
central government in the global competition, announced by President Chen in his 2000 inauguration speech. Taking populism at its face value, it should empower the local governments and communities, particularly those supportive of the DPP regime, to avoid marginalization. It was true that the new infrastructures were constructed and new allowances were made for the local people, particularly aged and retired citizens in the rural areas. Additionally, particularly during the election campaign, the local communities often found room to bargain for their better interests. Under such circumstances, the central DPP government took steps to cultivate its support beachheads at the local level. It summoned some of the KMT local factions and supported them in their confrontation with the ruling clique in local government.

In many cases, the governors of the ruling DPP could organize to oppose the local governors of the KMT, and thus relieve the central government of the guilt of oppressing the local communities. For example, the governor of Taipei County, a DPP political heavyweight, always pointed the finger at the Mayor of Taipei City, a KMT rising star, as being greedy and selfish and not taking care of other local governments' demands when it came to the allocation of tax revenues. In fact, the political conflict between the central state and the government of Taipei caused the delay of new infrastructure construction in Taipei City. This caused the shortage of hard infrastructure in the city. According to a report by the city government, the availability rate of sewage construction in Taipei was even lower than in Bangkok, at just 46\%, (TCG, 2001).

Under the slogan of promoting bottom-up development, the DPP local governors organized regional coalitions, such as the Kaohsiung City-Kaohsiung County-Pingtung County Alliance, to strengthen their collective bargaining power in solving regional governance issues such as river dredging, garbage collection and transportation planning. It seemed the local government took advantage of party politics to voice their concerns and attract attention from the central level. However, in fact, the central government still controlled the resource allocation, policy-making and implementation in the everglobalizing setting of Taiwan. The local governments had no power to make decision on economic affairs. What they could do to attract business was to change the land regulation and control the road construction. Key policies, such as the definition of strategic industries and the type and scope of incentives, were strictly controlled by the central government. Even key personnel matters, such as policing and fiscal management, were handled by the central government. Moreover, business revenue was pooled nationally and distributed as part of local authorities' overall funding allocation, which was usually driven by the central government's political considerations. It is farfetched to argue that devolution had occurred in the neoliberalized Taiwan. It is the nation state, rather than the local governments, that controlled the policy making.

Unlike the KMT developmental state, which embedded the redistribution of resources in its own political institutions as local factions, the DPP government offset the poverty of the 'losers' and their regions with direct pecuniary subsidies. The redistribution issue became thorny in the neoliberalization process in which the tax base was eroded by government handouts to business groups, particularly at the local levels, since most of the land taxes were the pillar of local fiscal income but were ordered to waiver by the central government. This led to a NT $\$ 80$ billion deficit for each local government. Ironically, political populism reinforced, rather than weakened, the control of the central government in allocating the resources to subsidize the obedient local governments.

\section{Critical evaluation of regional development}

In retrospect, the practice of neoliberalism-cum-populist regime was born when the KMT leader Lee Deng-hui resorted to the support of ethnic Hoklo communities, local factions, and business groups in the power struggle with the dominant mainlander group within the KMT in the political transition of the 1990s. But, there is no doubt that this seed blossomed and bore fruit after the DPP regained power. In other words, the DPP replaced the KMT as the ruling party in the 2000 presidential election in name only. In reality, only slight changes occurred as a result of the transition process. The DPP “inherited" a state machinery of political populism and economic neoliberalism from its precursor. The only critical difference was that the populist Lee Deng-hui enjoyed a strong party machine with the majority of the seats in both congress and local governments, unlike his successor Chen Shuibian. Instead of seeking out a political compromise with the KMT majority or breaking with the neoliberal line, which was criticized as unjust by the DPP, the DPP regime made things worse by intensifying neoliberalization projects such as financial monopolization and privatization on the one hand, and establishing political turfs through the institutionalized granting of political favors. This subtle change became inevitable when party politics arose and democratization and liberalization imposed the ruling party to build new alliances in the power struggle. In the process of reshuffling power, the DPP resorted to populism and mobilized place and ethnicity-based, rather than class-based, supports.

According to Lin (1989), 79.1\% of the DPP's votes came from working class and petty bourgeoisie (mostly small business, selfemployed entrepreneurs, and professionals) in the late 1980s, during the early stage of its foundation. This pattern remained intact until the presidential election in 2000. In appearance, the DDP should have mobilized class-based interest. However, the DPP never became the voice of the working class for several reasons. First, an overwhelming majority (96.5\%) of those who voted for DPP belonged to the Hoklo ethnic group. Moreover, all of the DPP candidates were also members of the Hoklo community. In contrast, high ranking officials in the KMT regime, particularly in the areas of national defense, economic planning and diplomatic affairs, were almost overtaken by the mainlanders before the late 1980s. Second, the patron-clientelist regime of KMT was effective in averting the potential class conflict, as individual workers would be compensated in case of labor disputes by searching for legal and economic assistance from local politicians without direct confrontation with individual capitalists (Wu, 1987). The collective class contradiction was appeased by individual favor bestowing. Surely, there existed a limit for the individualized practice to absorb class discontent; but such individualization nevertheless postponed the massive eruption of class conflict. Consequently, class issues were not the major contradiction for the DPP to fight with the KMT. Third, the small business dominated economy was not a good arena for class struggle, as most workers expected to become the bosses of their own small workshops, rather than the leaders of worker movements. The consciousness of "class for itself" was weak among worker groups. In fact, some contradictions existed between the two pillars of the DPP supporters, the worker and the small business people, as the latter usually benefitted from the over-exploitation of the former (Shieh, 1992). In a nutshell, exploiting ethnic differences would be a more convenient strategy than playing on class divisions for the DPP to engage in a power struggle with the KMT.

Things became more complicated after the DPP won the presidential election in 2000 and place-based interest emerged as another issue for the DPP to manipulate in the new round of power struggle. As shown in Hsu and Cheng (2002), although Taiwan is a country with relatively little land area, it has at least three distinctive regional economies, each with their own unique trajectories and crucial conjunctures of industrial development. While the state played an aggressive role in promoting new 
industries, such as that of semiconductors, most of the key industries were located in the Northern region, which also hosted major universities, research institutes, hospitals, and government agencies. Additionally, even most of the companies that sited their manufacturing facilities in other regions and headquartered in this region had to pay business taxes in the North, but owed nothing in taxes to the manufacturing regions. In contrast, most of the agriculture population concentrated in the South, and the smallmedium sized firms of traditional sectors clustered in the Central region. A placed-based discontent pervaded in the public forum, thus resorting to even development became a desirable strategy. Moreover, as most of the mainlanders who were political refugees after the KMT lost in the civil war settled down in the North, making the Northern region the solid turf of the KMT. But the majority population of the South was Hoklo people and was composed of potential supporters for the anti-KMT forces. In other words, the ethnicity-cum-place based interest became the key axis of the power struggle for the DPP politicians to maneuver.

It is true that most capitalist states tend to implement regional redistribution policies in order to alleviate regional economic disparities. Growth and equity considerations remain a central issue and a constant tension for regional development (Pike, Rodriguezpose, \& Tomaney, 2006). In a sense, a more progressive regional redistribution in the neoliberalism-cum-populist regime than in the neoliberal state would be expected. But, reality reflects a much different picture.

On the one hand, in adopting neoliberal policies the DPP state had to make concessions to business groups in terms of land and tax to obtain political support and donation. This resulted in the rapid rise of fiscal debt due to the erosion of taxation bases. The rate of unpaid debt to GDP increased from less than $5 \%$ in 1990 to $31 \%$ in 2007. In other words, taxation from accumulated capital and payment transfers to the deprived in the neoliberalization process did not occur as justified by neoliberal advocacy. Moreover, to curb the fever of "going China", the DPP state provided more special incentive packages to retain high-tech firms, in addition to legal punishment, such as the launching of the Taichung Park. Consequently, taxation did not become the tool of redistribution.

On the other hand, rather than fostering endogenous development in the peripheral regions, the populist state often resorted to regional disparity as a political mobilization strategy and preferred gift bestowing as the main method of resource transfer. By doing so, the leaders of the populist regime gained and accumulated their political capital easily. Under the confinement of the KMT in congress and in local factions, the populist DPP government detoured to mobilize local communities mainly by subsidizing infrastructure construction and social grant. In most cases, the resort to populist rhetoric, such as "we pay tax and we are not second-place citizens," was mostly raised as the slogan in the fight for resources, such as science and technology parks, international airports, and so on. Similar infrastructures repeatedly appeared across the island.

The situation became complicated when the vote calculation was accounted into the distributive project. The ameliorating fiscal budget, in combination with suppressing the potential threat from leading KMT politicians, led the DPP government to adopt a zerosum game as the solution to the problem of regional disparity. Consequently, the competitiveness of Taipei City declined due to a lack of financial support. Even the Southern and the Central Regions, which were supposed to be the key beneficiaries of the redistribution policies, did not gain enough growth momentum to transform developmental paths, ${ }^{8}$ but hosted a number of "mosquito facilities," a mocking term to refer to those facilities that could not be used efficiently and were discarded to mosquito proliferation (TMJ, 2005).
The case of launching Taichung Park is particularly at stake here. The idea of the third science and technology park came from the DPP government soon after the 2000 presidential election. Taking advantage of a cleavage among the KMT leaders, most of the votes the DPP won were from the South, while the KMT strongly held the North. Thus, Central Taiwan became the target to win if the DPP intended to win in the 2004 re-election. Under such consideration, the slogan of "three thirds - the third major international airport, the third central-government-controlled-municipality, and the third science and technology park" besides the North and the South, was raised as a policy issue. Finally, the Taichung Park opened in 2002. Since Taiwan was hit heavily in the decline of rural industrialization after the 1980s, the Taichung Park was designed to retain and revive the traditional industrial base in central Taiwan, especially the machinery industry. In contrast with the Hsinchu Park, which was planned and designated by technocrats, the development of Taichung Park was the subject of fierce competition between the counties in the Central region. Local politicians and congress-people were deeply involved from the beginning and lobbied aggressively for the president's endorsement of exchanging their political supports. As a result, the Park adopted the developmental model of "one park, several sites" which covered most of the neighboring counties, even including Yun-lin County, which was located more than 100 miles away from Taichung City. The disputes around the site selection did not settle after the Park was opened (Feng, 2002). It remained unclear if the Taichung Park could reach its goal to promote the upgrade of traditional industries, but its electoral contribution was definitely obvious; in the 2004 presidential re-election, the DPP won in central Taiwan, which was historically KMT's territory.

The policy goal of the construction of the Taichung Park was to reduce the regional economic disparities in addition to economic development. It is difficult to comprehensively evaluate this issue here due to space limitations, but a broad outlook might be possible. In fact, most of the member firms of the Taichung Park came from neighboring areas, mainly from the Taichung Industrial Park and Hsinchu Park. Few of them were new firms. In other words, the Park was basically a special zone for established firms to relocate or expand their operations. It is hard to argue the Taichung Park has significantly impacted local economic development, given the huge cost of development of a new science and technology park.

Moreover, among the three Park sites, only the Taichung core site has been in use; the remote park in Yun-lin County has hosted only two public agricultural laboratories thus far! In fact, the huge expense of the park construction could be used in an efficient way, such as to engender and promote research teams among the machinery firms in the Central Region, assuming it was possible to reduce regional disparities. However, under populist rhetoric and political calculation, a science and technology park will be more attractive to the DPP government as land development and speculation induced by the "park fever" has become the key interest and discourse to mobilize supports from local politicians and business groups (Liu, 2007).

Another example of populist decision-making is that of the Taichung International Airport, which was originally built for military use and was a NT\$1.5 billion project (around US\$50 million). Despite professional evaluations that did not reveal sufficient demand for such a facility, President Chen opened the airport, as he had promised in his election campaign. However, political decisions could not replace market logic, and only three flights took off from this "international" airport each week during the first six months. A similar scenario occurred in Pingtung County, in the far south end of Taiwan. One new airport, which was located within $10 \mathrm{~km}$ from the existing Kaohsiung airport, was constructed as a testament to the caring nature of the DPP government. Though US\$100 million was 
spent, the terminal more often than not remains vacant according to TMJ (2005). This demonstrates that top-down resource allocation has been influenced and distorted by populist decision-makings of central powers which prioritize political clientism over regional development.

The consequence of the neoliberalism-cum-populist regime was double disappointments for its supporters. Neoliberalization did not create economic benefits to spread to the deprived people due to a number of concession measures. At the same time, populist strategies did not engender sufficient growth momentum and employment opportunities to sustain political loyalty. Worst of all, resorting to personal charisma without institutionalized monitoring always breeds corruption and injustice. A series of scandals burst out in 2006 and caused a million people walk to the street to protest the corruption of President Chen; these people are testament to the frailty of the neoliberalism-cum-populist regime. Ironically, the ghost of corruption that collapsed the KMT regime in 2000, haunted the DPP in return. Finally, the KMT candidate, the Major of Taipei City, who was commonly believed to be a clean man without strong executive capabilities, defeated the DPP in a historical landslide of $17 \%$ in the 2008 presidential election. Even Kaohsiung City, the bastion of the populist regime and whose Mayor was the DPP candidate (but whose city suffered from a high unemployment rate of over 5\%), was captured by the KMT.

\section{Conclusion}

The key lesson learned from the story of the neoliberalism-cumpopulist DPP regime was the symbiotic emergence of the roll-back of state intervention in economic development and the roll-out of state subsidization in social spending. A retreat of state intervention at the national level linked to the state itself rolling forward at the local or regional level. The political drive sharply dismantled the authoritarian regimes and opened up flaming power struggles among political leaders who might easily mobilize direct, unmediated, uninstitutionalized support from large numbers of mostly unorganized followers. Emphasizing and creating regional disparities became a convenient ploy to summon the spontaneous mass without the necessity of responding to organized interest.

Generally speaking, the spatiality of neoliberalism was mainly characterized by uneven development, since the market mechanism was let loose by the state, which was used to support dilapidated cities and regions. The agenda of neoliberalism, which consisted of policies of deregulation, privatization, the removal of barriers to the mobility of financial capital, was favorably inclined to the new industrial spaces and put downward pressure on the declining places. In most cases, the sparkling places, such as the Hsinchu-Taipei corridor in the northern region, were usually those that hosted rising industries such as high-tech, culture and design and high-end professional service industries, which constituted the base of regional competition. In contrast, gloomy areas, such as the southern region, that lacked the innovative milieu and mostly the low-end labor intensive industries and low-productivity agriculture sectors resided were facing relentless competition or were just ignored by the new development impetus.

In fact, many government actions aimed to promote re-election chances which were usually geographically structured within the subnational territories were not necessarily nationally or globally embedded. Different policies were pursued on different scales. The DPP state was a "vacillated state", which pulled and dragged itself between the pro-growth stance of neoliberalization project and the populist platform of redistribution. This resulted in new scale politics in which the fate of the urban regions was closely tied with the global economic growth and the rural areas articulated tightly with domestic resource allocation. Contradictions often appeared in the state plan as it lost its policy effectiveness as the model of developmental state expected. It was truly a state in dilemma.

\section{Acknowledgement}

I sincerely appreciate Neil Brenner, James Sidaway, Bae-gyoon Park, Jim Glassman and the anonymous reviewers for constructive comments on the earlier version. I would also like to thank the following funding agencies for supporting the research on which this paper is based: the National Science Council (grant\#: 96-2415H-002-021-MY3), and the Program for Globalization Studies (grant\#: 97R0064-15) of the Institute for Advanced Studies in Humanities and Social Sciences at NTU. I am responsible for all errors and/or mistakes.

\section{Endnotes}

${ }^{1}$ This meant that the existence of many banks led to a lack of competitiveness of individual banks. In 2005, the market share of the top five banks was only $38 \%$ in Taiwan, in comparison with $89 \%$ in Korea, $76 \%$ in Hong Kong and 93\% in Singapore. ${ }^{2}$ After meeting with his economic councilors in October 2004, President Chen claimed that the total number of FHCs had to be reduced from fourteen to seven and the total number of state-owned banks to six by the end of 2005 .

${ }^{3}$ For example, Cathay group increased its financial assets from NT\$1130 billion in 2001 to 2650 billion in 2004. Similar increases applied to other FHCs too.

${ }^{4}$ It was frequently reported that the friends and staff of the first family were granted the positions of general managers in a number of key SOEs, such as Chung-Hsing Paper company and China Steel, among others.

${ }^{5}$ For example, Yuantai group purchased a lot of state-owned land with NT\$1.2 billion, and constructed houses for sale. The sale was expected to reach 3.6 billion, a $200 \%$ profit.

${ }^{6}$ The mission of the Tainan Park project - to distract Taiwanese high-tech investors from China - was vividly described by the director in his inauguration speech in which he persuaded the Hsinchu semiconductor firms not to go China, but to stay in Taiwan. He said, "Going south (Tainan) would be a better choice than going west (China)". (Jan. 26, 2003 Liberty Times)

${ }^{7}$ Before the change, the president was elected by the 300 representatives of national assembly. The majority of them were not elected by Taiwanese people but stayed in position before the national government regained power in the mainland, according to amendments to the constitution. People taunted them as being "million year delegates".

${ }^{8}$ The regional disparity can be measured in the gap of per capita income. According to official statistical data, the gap in per capita income between the Northern and the Southern Region increased from NT\$81,000 in 2001 (the first year of the DPP administration) to NT\$99,000 in 2005.

\section{References}

Amsden, A., \& Chu, W. (2003). Beyond late development: Taiwan's upgrading policies. Cambridge: The MIT Press.

Brenner, N., \& Theodore, N. (2002). Spaces of neoliberalism: Urban restructuring in North America and Western Europe. Malden: Blackwell.

Brohman. (1996). Postwar development in the Asian NICs: does the neoliberal model fit reality. Economic Geography, 72(2), 107-130.

CEPD. (2004). The statistical collection of urban and regional development. Taipei: Council of Economic Planning and Development. (in Chinese).

Ching, C.-H. (2001). Globalization and the development of producer services in Taiwan's metropolises. City and Planning, 28(4), 495-518, (in Chinese).

Chu, W. (2003). Taiwanese economy in globalization. Taipei: Tang-Shan Publisher. (in Chinese).

Chung, C. (1997). Division of labor across the Taiwan Strait: macro overview and analysis of the electronics industry. In B. Naughton (Ed.), The China circl. Washington, DC: Brookings Institution.

Executive Yuan. (2003). Challenge 2008: National strategic development plan, 20022007. Taipei: Executive Yuan. (in Chinese)

FSC. (2008). The statistical report on the distribution of financial service. Taipei: The Financial Supervisory Commission. (in Chinese).

Gough, J. (2002). Neoliberalism and socialization in the contemporary city: opposites, complements and instabilities. In N. Brenner, \& N. Theodore (Eds.), Spaces of neoliberalism: Urban restructuring in North America and Western Europe. Malden: Blackwell.

Harvey, D. (2005). A brief history of neoliberalism. Oxford: Oxford University Press.

Hsu, J. (2005). A site of transnationalism in the "ungrounded empire": Taipei as an interface city in the cross-border business networks". Geoforum, 36(5), $654-666$.

Hsu, J. (2006). From regional collaboration to regional fragmentation: neo-liberalization, state transformation, and scale politics in Taiwan. Presented in the 
102nd Annual Meeting of the Association of American Geographers, Chicago, USA, March 07-11, 2006.

Hsu, J., \& Cheng, Lu-lin (2002). Revisiting economic development in post-war Taiwan: the dynamic process of geographical industrialization. Regional Studies, 36(8), 897-908.

Huang, L. (1996). The changing role of community in the construction of new country: A discursive analysis of 'Destiny community'. Master's thesis, Graduate Institute of Building and Planning, National Taiwan University (in Chinese).

Jessop, B. (2001). Institutional (re)turns and the strategic-relational approach. Environment and Planning A, 33(7), 1213-1235.

Jessop, B. (2002). Liberalism, neoliberalism, and urban governance: a state-theoretical perspective. In N. Brenner, \& N. Theodore (Eds.), Spaces of neoliberalism: Urban restructuring in North America and Western Europe. Malden: Blackwell.

Johnston, R., \& Glasmeier, A. (2007). Neo-liberalism, democracy and the state: temporal and spatial constraints to globalization. Space and Polity, 11(1), $1-33$.

Larner, W. (2003). Neoliberalism? Environment and Planning D, 21, 509-512.

Larner, W. (2005). Neoliberalism in (regional) theory and practice: the stronger communities action fund in New Zealand. Geographical Research, 43(1), 9-18.

Leyshon, A., \& Thrift, N. (1997). Geographies of financial exclusion: financial abandonment in Britain and the United States. In Leyshon., \& Thrift. (Eds.), Money/space: geographies of monetary transformation. London: Routledge.

Lin, C. (1989). Oppositional movement under an authoritarian-cientelist regime: social base of the democratic progress party. Taiwan: A Radical Quarterly in Social Studies, 2(1), 117-144, (in Chinese).

Liu, J. (1992). An analysis of Taiwan's postwar economy. Taipei: Ren-Jian Press. (in Chinese).

Liu, P. (2002). The triangular structural analysis of the state, local factions and the credit union in the developmental experience of Taiwan. PhD. dissertation, Sun Yat-sen Institute of Humanity and Social Studies, National Cheng-chi University. (in Chinese).

Liu, Y. (2007). The analysis of the Taichung Park and the developmental trend of the central Taiwan. Presented in the annual meeting of the Central Taiwan Regional Competitiveness Society, May 25, 2007 (in Chinese).

MacLeod, G. (2001). Beyond soft institutionalism: accumulation, regulation, and their geographical fixes. Environment and Planning A, 33(7), 1145-1167.

OURs. (2006). The national land for sale: How the business groups buy the state-owned land cheap. Taipei: The Organization for Urban Res. (in Chinese).

Palermo, V. (1998). Moderate populism. Latin American Perspective, 25(4), 36-62.

Park, B.-G. (2005). Spatially selective liberalization and graduated sovereignty: politics of neo-liberalism and "special economic zones" in South Korea. Political Geography, 24(7), 850-873.

Peck, J. (2004). Geography and public policy: constructions of neoliberalism. Progress in Human Geography, 28, 392-405.
Peck, J., \& Tickell, A. (2002). Neoliberalizing space. In N. Brenner, \& N. Theodore (Eds.), Spaces of neoliberalism: Urban restructuring in North America and Western Europe. Malden: Blackwell.

Pike, A., Rodriguez-pose, A., \& Tomaney, J. (2006). Local and regional development. London: Routledge.

Roberts, K. (1995). Neoliberalism and the transformation of populism in latin America. World Politics, 48(1), 82-116.

Rodríguez-Pose, A., \& Gill, N. (2003). The global trend towards devolution and its implications. Environment and Planning C, 21(3), 333-351.

Rossi, U. (2004). New regionalism contested: some remarks in light of the case of Mezzogiorno of Italy. International Journal of Urban and Regional Research, 28(2), 466-476.

Sachs, J. (1989). Social conflict and populist policies in Latin America. Working Paper \#2897. National Bureau of Economic Research.

Scott, A., \& Storper, M. (2003). Regions, globalization, development. Regional Studies, 37(6\&7), 579-593.

Shieh, G. S. (1992). 'Boss' Island: The subcontracting network and micro-entrepreneurship in Taiwan's development. New York: Peter Lang Publication Inc.

TCG. (2001). The white paper of Taipei city. Taipei: Taipei City Government. (in Chinese).

The Control Yuan. (2001). The report of the comprehensive investigation on the community empowerment projects. Taipei: Yuan-Liu Publisher. (in Chinese).

TMJ. (2005). A report on the waste of infrastructure construction. Taipei: The Ministry of Justice.

Tsai, M. (2001). Dependency, the state and class in the neoliberal transition of Taiwan. Third World Quarterly, 22(3), 359-379.

Valverde, C., \& Fernandez, R. (2004). The finance-growth nexus: a regional perspective. European Urban and Regional Studies, 11(4), 339-354.

Wang, C., \& Kurzman, C. (2007). Dilemmas of electoral clientelism: Taiwan, 1993. International Political Science Review, 28(2), 225-245.

Ward, K., \& Jonas, A. (2004). Competitive city-regionalism as a politics of space: a critical reinterpretation of the new regionalism. Environment and Planning $A$ 36, 2119-2139.

Weyland, K. (2003). Neopopulism and neoliberalism in Latin America: how much affinity? Third World Quarterly, 24(6), 1095-1115.

Wu, N.-T. (1987). The Politics of a Regime Patronage System: Mobilization and Control within an Authoritarian Regime. PhD. dissertation, Department of Political Science, Chicago University.

Xia, C. (2005). The dinner of a vulture: The societal consequence of financial acquiring and merging. Taipei: The Union of the Employees of Banks. (in Chinese).

Zhang, J. (1989). The road to power. Taipei: South Press. (in Chinese).

Zhang, T. (2005). "Neo-liberalism and the transformation of KMT'S government -business coalition". Paper presented in the colloquium of "rethinking the East Asian states: Political logic and production network", Taichung: Tungha University. 